Mihai A. Panu

West University, Department of Political Science (Timisoara)

\title{
Alternative diplomacy and the political role of clerical elites: \\ The Roman Catholic Church as an ideological \\ counterforce in interwar Banat
}

\begin{abstract}
In interwar Romania, non-political institutions played a decisive role in the process of containing the expansion of totalitarian ideologies. The two major colliding ideological forces, National Socialism and Communism, rapidly reshaped the European sociopolitical profile after World War I and caused an unprecedented long-term deterioration of various intergovernmental relations. The Banat region was systematically exposed to external ideological factors due to the fact that its heterogeneous ethno-cultural profile allowed a rapid proliferation of political ideas and programs.

This paper attempts to analyze the public role played by the Roman-Catholic clergy of the diocese Timişoara, in the context of rising National Socialist propaganda pressure, between 1930 and 1944. The most important clerical personality, who acted as a veritable counter-ideological element and therefore as a symbolic social protecting power, was the former bishop of the diocese Timişoara, Dr. Augustin Pacha.
\end{abstract}

Keywords: NS-ideology, Banat, Catholic Church, Augustin Pacha, propaganda, diplomacy

\section{Introduction}

In the $20^{\text {th }}$ Century, most European societies were affected in varying degrees by the primacy of totalitarian ideologies. The geopolitical legacy of World War I and its subsequent systemic imbalances represented the breeding ground for the forthcoming unprecedented radicalization of the sociopolitical sphere. In the continental state-system, the balance of power remained sensitive even if some institutionalized mechanisms of peacekeeping (such as the League of Nations or various bilateral treaties) were officially agreed and operative. The emerging nation-states in Eastern Europe were particularly exposed to ideological ex- 
tremism mainly because of their insufficient institutional consolidation but also as a result of external propaganda pressure. This was also the case of Greater Romania. Confronted with the two main ideological players of the interwar period, National Socialism and Communism, the Romanian society and party system soon became a battleground for opposing political forces. Despite their multicultural heritage and plural sociopolitical profile, some distinct regions in Romania such as the Banat also experienced major political and social upheavals. These particular phenomena were caused by a series of concurrent factors: the reconfiguration of intra-societal relations after the Great Union, the rise of genuine integral nationalism, the economic instability, the external geopolitical interference and the incapacity of the Romanian political class to optimally manage the new ideological challenges.

This paper attempts to investigate the manifestation of totalitarian ideologies in interwar Banat and the key-role played by the Catholic Church as ideological counteracting force. In the process of containing the impact of totalitarian ideologies, were involved not only political institutions or parties but also various non-political players. In the Banat region, one of the most important traditional social players was the Roman-Catholic diocese and its clergy. Given the fact that the political history of Banat still remains a neglected approach in the Romanian (but also European) scientific literature, unedited archive material represents the main source of information for our analysis. This does not mean that valuable research has not been done during time (especially after the fall of Communism) on the general topic of political history in interwar Romania, but the particular issue of politics and religion (seen as a driving force of societal processes in the Banat region) was not systematically described and analyzed.

After the Great Union in 1918, the institutional design of the Romanian state had to be changed and adapted to the new social and political realities. One of the most important political issues in the Romanian interwar society was the problem of minorities and their political representation. The government unnecessarily delayed the promulgation of a minority law (Maner, 2004, p. 305), ignoring thereby the legitimate constant demands and petitions submitted by the representatives of various minorities. The biggest challenge for the centralized Romanian political system at that time was to gain the loyalty of all ethno-cultural groups. Considering that an artificially constructed political identity of Greater Romania not always corresponded to the socially and culturally constructed sense of community, especially in the new incorporated regions (such as the Banat), a fundamental societal discrepancy becomes obvious. Likewise, an important political issue was the attitude of the Romanian majority towards leading minority groups. The better economic condition of some minorities (such as Germans and Jews) made various political connections possible and consequently strengthened their political influence both at local and central level. This general perception altered the relations at societal level to such an extent that the Romanians became mistrustful and even anxious towards the most important minority groups (Sugar, 2002, p. 236). In interwar Romania, the struggle to create a genuine national identity represented a complex political undertaking. The idea of a nation-state had to be 
constructed first of all as an ideological dominant discourse. Such strategies presupposed a certain degree of social differentiation in order to systematically construct the idea of national identification and solidarity:

"Constructive strategies are the most comprehensive discursive strategies. They attempt to construct and to establish a certain national identity by promoting unification, identification and solidarity, as well as differentiation. Strategies of perpetuation attempt to maintain and to reproduce a threatened national identity, i.e. to preserve, support and protect it" (Wodak et. al., 2009, p. 33).

Most of the ethno-cultural groups in interwar Banat were (more or less) ideologically instrumentalized and therefore used as social vectors for shaping a desired model of community consciousness and political affiliation. The various attitudes and mentalities in the Banat society were motivated and sustained by distinct factors. The most important stakeholders who played a decisive role in the process of configuring social actions and orientations were, in this particular case, two important institutions: the state and the church. Both state and church had to overcome the challenges of complex societal realities. After the Great Union (1918) the young Romanian state lacked the necessary political cohesion and experience needed for a long-term gain of genuine legitimacy. The problem of minorities representation (as highlighted above) played a decisive role in this particular case because (in many situations) the integrative power of Romanian policies was overshadowed by the temptation of Romanianization and political centralism. On the other side, the church had to reinvent itself in the light of changing political realities. The Roman-Catholic Diocese of Timisoara was a new institutional player (established in 1930) and therefore eager to show its potential as a societal player in the Banat region. In our view, this is the main reason for its "political" appetite and for the readiness to defend its legitimate interests by using non-traditional discursive strategies.

\section{Clerical Elites in Interwar Banat: A Brief Biography of Bishop Dr. Augustin Pacha}

Augustin Pacha was born in Măureni (Moritzfeld / Móriczföld) on November 26, 1870 (Petri, 1992, p. 1405) in a lower-middle class family. His father, Marian Pacha (1830-1882) had Czech origins and worked as a shoemaker to support his large family, while his mother Elisabeth Pacha (see Halsdorfer 1832-1931) was responsible for housekeeping. Augustin Pacha attended primary school in his native village (Călin, 2009, p. 213), afterwards followed secondary education in Kecskemét, Szeged (1881-1887) and Timişoara (1887-1889) (Petri, 1992, p. 1405). In June 1889 he passed the baccalaureate exam then, between 1889 and 1893, studied theology in Timişoara (Petri, 1992, p. 1405). On August 12, 1893 Pacha is ordained as a priest. Between 1893-1894 he worked as a chaplain in Mezőkovácsháza; between 1894-1896 he became protocolist Bishop and between 1896-1898 he conducted some specific clerical activities in Bucharest and Braila (Petri, 1992, p. 1405). On December 
6, 1901 Pacha became personal secretary of bishop Alexander Dessewffy ${ }^{1}$, a decisive moment for his future clerical career (Petri, 1992, p. 313). Between 1911-1923 he worked as a capitular of the Diocese Cenad and in 1912 he became director of the episcopal chancellery (Petri, 1992, p. 1405).

After the historical decision of Bishop Julius Glattfelder (1874-1943) to continue his episcopal mandate in Szeged, Augustin Pacha, was appointed on March 12, 1923, as an Apostolic Administrator of the Diocese Cenad ${ }^{2}$ (Călin, 2009, pP. 230-231) and on April 3, 1927, he received the title "Titular Bishop of Lebedo" (Petri, 1992, p. 1406). The following year, on March 1, 1928, Augustin Pacha received the title „Doctor Honoris Causa” from the University of Münster (Kräuter, 1995, p. 93). On June 11, 1929, the concordat between Romania and the Vatican was ratified and, one year later, on June 5, 1930, the denomination "Diocese of Timişoara" was officially communicated. (Petri, 1992, p. 1406). This was an important moment and a decisive personal success for Augustin Pacha. The period of uncertainty and his provisory mandate as an Apostolic Administrator therefore ended and a new era was about to begin. Shortly after this event, on October 16, 1930, Augustin Pacha officially became diocesan bishop of Timisoara (Petri, 1992, p. 1406). After his appointment as a bishop, Pacha had to face unprecedented political challenges in the context of rising extremist and highly anticlerical ideologies. The emergence of radical political trends in Romania and the geopolitical configuration in Europe, led to a necessary change in the behavior of the clergy. Bishop Pacha had to prematurely face increased national and international ideological pressure. His complex personality and strong sense of diplomacy transformed him into a veritable regional social player.

Augustin Pacha was the first German bishop in the new diocese of Timişoara. During his incumbency, Pacha tried to systematically promote the German language and culture among his congregation. Likewise, he initiated some important development measures for the German confessional education system in Banat. After years of continuous Magyarization attempts during the Austro-Hungarian dualism, the German minority in Banat nearly lost its cultural and political consciousness. Consequently, the cultural heritage and identity features of the Banat Swabians were threatened by Hungarian assimilation. Augustin Pacha managed to positively reconfigure the attitude of the German minority towards its own cultural heritage and to rebuild a genuine sense of community among Swabians. In the following years (especially after 1933), Pacha had to face the National Socialist ideological pressure and various forms of political radicalism at local level. The emergence and development of local Nazi-organizations such as D.V.i.R ${ }^{3}$ (German Ethnic Group in

1 Alexander Graf Dessewffy de Csernek et Tarkeő, Bishop of Cenad, born on June 3, 1834 in Pressburg died on December 4, 1907 in Budapest (a.n.).

2 Pacha was only responsible for the Romanian part of the diocese (a.n).

3 D.V.i.R (Deutsche Ethnische Gruppe in Rumänien) (a.n.). 
Romania) became a serious concern for the catholic clergy in Banat, mainly because the leaders of these groups repeatedly attempted to transfer the catholic confessional schools into Nazi possession.

In this case, the clear objective of the Nazi ideological stakeholders was to take control over the catholic youth organizations (which were traditionally managed and supported by the diocese of Timişoara) in order to optimally carry out indoctrination and propaganda campaigns among them. The N.S. authorities knew that, compared to the older more conservative society level, the younger generations could be easily exposed to extremist propaganda factors and therefore rapidly indoctrinated. Knowing the fact that the youth organizations became a major stake for the Nazi propaganda, bishop Pacha and his followers tried to act as an ideological counterforce in order to contain the effect of National Socialist ideology in Banat. Pacha clearly understood that the best way to achieve such goals would imply a systematic presence of the church in the public space (discursively and symbolically) and, of course, the development of containment strategies, especially in confessional schools (where the NS-ideology was about to take roots).

The anti-totalitarian attitude of Bishop Dr. Pacha continued even after the end of World War II. The new political regime in Romania blamed the German minority in Banat for its presumptive collective National Socialist affiliation. Consequently, an unprecedented political repression process was initiated and carried out by the communist ideological stakeholders against the Banat Swabians. Bishop Pacha witnessed the massive deportation campaigns of his fellow citizens without suspecting that in the near future he will also become a victim of the communist repression.

On June 17, 1948 the concordat with the Vatican was unilaterally denounced (Kräuter, 1995, p. 47), the Catholic Church in Romania becoming therefore exposed to the arbitrariness of the communist regime. In July 1950, Bishop Dr. Augustin Pacha was arrested by the Securitate and, after a show trial orchestrated by the communists he was sentenced to 18 years in prison and 10 years loss of civil rights (Kräuter, 1995, p. 178). After nearly four years of hard carceral experience in Sighet and Bucharest (Kräuter, 1995, p. 181) the 84 years old Bishop was finally released from prison. The discharge decree was published in the Official Gazette on the evening of May 31, 1954 (Kräuter, 1995,p. 189). Seriously ill, the bishop died a few months later, on November 4, 1954 (Călin, 2009, p. 254).

\section{Instances of Radicalization in Multicultural Banat}

In interwar Banat the rise of political extremism significantly affected the pluralist profile of the society. The ideologically constructed ethno-cultural discrepancies became a key element in the extremist propaganda discourses and therefore in the process of ethnicity construction. In multicultural societies, the interactions between different groups and social categories represent the core idea of identity building. Therefore, both group identity and national identity are continuously negotiated and renegotiated over long periods. If 
perceived as a determinant factor in the process of identity formation, the term "ethnicity" has a particular importance mainly because it implies politically defined elements:

„Ethnicity is, (...) politicized social action, a process whereby elements of real, actual, lived cultural differences are politicized in the context of intensive group interaction" (Malesevic, 2006, p. 26).

The concept of ethnicity can be optimally used in order to investigate and highlight specific circumstances in the societal dynamics. First of all, it presupposes a certain political determinism, if understood as "politicized social action" (Malesevic, 2006). Secondly, it facilitates a proper analysis of various national antagonisms, because this complex concept can be also understood as "a cleavage within a nation, usually within a national state" (Smith, 1998, p. 45).

In ethno-cultural heterogeneous societies such as the Banat, the mechanisms of interactions between different groups are difficult to analyze, mainly because of their changing dynamics. Consequently, a powerful analytical tool is needed in order to optimally depict such multifaceted social realities. In this respect, the theoretical framework of ethnicity proves itself quite useful in the process of investigating social attitudes, tendencies, structures, etc. because it considers several elements that are crucial in the logic of individual and collective identity formation:

- "ethnicity is a matter of cultural differentiation (bearing in mind that identity is always a dialectic between similarity and difference);

- ethnicity is a matter of shared meanings - 'culture' - but it is also produced and reproduced during interaction;

- ethnicity is no more fixed than the way of life of which it is part, or the situations in which it is produced and reproduced; and

- ethnicity is both collective and individual, externalized in social interaction and the categorization of others, and internalized in personal self-identification" (Jenkins, 2008, p. 169).

The societal profile of interwar Banat was decisively determined by the mechanisms of ethnicity. Overcoming the arbitrariness of ethnicity proved itself to be a major challenge for the social and political stakeholders both at regional and national level.

During the interwar period totalitarian ideologies tried to indoctrinate the society and control the public sphere in such a manner that any kind of opposition would be impossible. For the National Socialists, the biggest challenge was to undermine and eventually eliminate other societal players, especially the ones that were involved in the process of setting the public agenda. In Banat, the most important traditional societal player was the Roman-Catholic Church and its clerics. The N.S propaganda campaigns were intended to systematically eliminate other forms of social authority such as the clerical one and to establish a new, ideologically constructed, community profile. In order to accomplish this goal, the ideological stakeholders had to act subversively and to develop a credible discourse strategy. For Nazi-Germany, the Catholicism represented nothing less than an ideological 
counterforce and an unacceptable parallel authority form. Both, ideology and religion claimed the legitimate control over society although the power of Catholicism, in comparison with National Socialism, was rather traditional and symbolic than economic or military: "The political power of Catholicism rests neither on economic nor on military means but rather on the absolute realization of authority". (Schmitt, 1996, p. 18). However, their common goal was to exercise a certain social authority and to gain the loyalty of the masses.

In interwar Banat, an important part of N.S-Propaganda was necessarily anti-clerical. The rivalry between religion and ideology originated (as described above) in the same critical point: both claimed the same role as social players and both tried to control the public agenda. From National Socialist point of view, the existence of another legitimate authority form at social level was completely inacceptable, mainly because the clerical authority had the potential to delegitimize the Nazi ideological power.

The geopolitical pressure of N.S-ideology became a serious problem for the diocese of Timişoara, already in 1931 as the first national socialist organizations were established in Jimbolia (under the leadership of Karl von Möller and Peter Maurusz), Aradul Nou (Franz Stoss and Peter Bernath), Perjamosch/Periam (Rudolph Ferch and Franz Adam Minnich) and Timişoara (Geisa Buding and Peter Schmidt) (Hockl, 1940, p. 57). The institutional infrastructure of National Socialism was developed in the following years, in most cases with German financial and logistic support. During World War II, the manifestations of N.S-ideology in Banat reached their maximal intensity. In September 1940, the German Ethnic Group in Romania (Deutsche Ethnische Gruppe in Rumänien) was founded (Milata, 2009, p. 77). This organization, led by Andreas Schmidt, a Transylvanian Saxon SS-officer (Bundesarchiv, NS 19/1077, p. 9) and directly controlled by N.S.D.A.P, was declared by Ion Antonescu on November 20, 1940 to an institution of public law (Böhm, 1999, p. 313). Consequently, the German Ethnic Group had a large decisional autonomy and functioned more or less as a veritable "status in status" (state within a state).

From National Socialist point of view, the most disputed issue in interwar Banat was the administration of German educational facilities. After the Great Union from 1918, the new Romanian state tried to stimulate the development of German schools all over Banat in order to rebuild the German cultural identity, which was previously affected by the systematic process of Magyarization and thus to gain the loyalty of most Banat Swabians. Because of strong governmental promotion, the education in German language was available in many communities. A brief overview of the Banat Swabian school system between 1934 and 1936 illustrates the following situation: (Hügel, 1957, pp. 18-19).

- 16 denominational schools and colleges with around 2000 pupils and 140 German teachers (The "Banatia", founded on September 26, 1926 with significant support of the Catholic Church, had become the most important cultural center of the Banat Germanhood);

- About 65 denominational primary schools with about 9700 children and 165 German teachers; 
- A state boys' secondary school with about 500 students and 12 German teachers;

- In addition, about 115 -government primary schools with approximately 21,500 children and 300 German teachers.

In addition to the confessional schools administrated by the diocese of Timişoara, there were also various church-related organizations such as "Der Deutsch-Katholische Jugendbund" (The German Catholic Youth League), "Die Katholische Deutsche Mädchenkränze" (The Association of German Catholic Women), (Der Ruf, 1937, p. 4). Together, these two organizations had in 1934 approximately 12.000 members (PA AA, 136/2587, D.I.A-3).

In Banat, after the emergence of the first national socialist groups in 1931 (Hockl, 1940, p. 57), the educational establishment and the youth organizations administrated by the Catholic Church, became a strategic target for the Nazi ideological decision makers. Their main objective was to rapidly gain political access to these youth organizations and educational facilities for indoctrination purposes. However, the Nazi attempts to control educational facilities and youth organizations in Banat, encountered a fierce reaction of the Catholic Church. Eventually during World War II, despite intense opposition, the infamous German Ethnic Group (Deutsche Ethnische Gruppe in Rumänien) took control over most confessional schools previously administrated by the Church.

\section{Augustin Pacha's Clerical Diplomacy: The Meeting with Chancellor Adolf Hitler}

The meeting between Bishop Dr. Augustin Pacha and the German Chancellor Adolf Hitler on February 22, 1934 (Kräuter, 1995, p. 124) was an event that had a particularly strong impact in the Romanian public sphere and also significant long-term consequences. Beyond the sensationalist way in which the press reported the event, Pacha's visit to Hitler has to be placed in a broader political and geopolitical context. The fact that a Roman Catholic cleric had direct talks with the National Socialist leader does not automatically mean that bishop Pacha has to be incriminated on the basis of a presumptive adherence to the principles of a totalitarian ideology. His decision to address the Chancellor Adolf Hitler was motivated by the following circumstances:

1. At the end of 1933 and beginning of 1934 , National Socialism was present in various forms in the Romanian Banat. As mentioned previously, one of the most important ideological vectors was the systematic propaganda among young people, especially in educational institutions. In certain confessional schools, such as "Banatia", some teachers promoted the ideas of Nazism and Pan-Germanism among students. This undesirable phenomenon was quickly noticed by the former "Banatia" director Josef Nischbach who immediately informed Pacha about that fact. Most propaganda vectors in Banat were supervised by the Nazi officials in Berlin, even though their involvement was not officially recognized. The 
diocese of Timişoara tried to solve the problem of Nazi propaganda by using diplomatic means. The clerics made the first step, in an unprecedented attempt to persuade the Nazi authorities, that the agitators controlled by the Third Reich represent a serious threat for the Romanian-German bilateral relations and for the German minority in Banat. If such events should have been known by the Romanian Ministry of Education, the German schools in Banat would most likely have been closed, particularly because the Romanian authorities were engaged in an open conflict with the radical right-wing groups, especially after the assassination of Prime Minister I.G. Duca in December 1933. In these circumstances, it is quite understandable that the Roman Catholic Diocese of Timişoara, hesitated to discuss the issue with the Romanian government agencies and preferred instead to solve the problem by directly approaching the German officials.

2. The National Socialist propaganda campaigns significantly affected the societal profile in Banat. Not only the Roman Catholic clergy but also some political representatives of the Banat Swabians showed their deep concern and dissatisfaction with the Nazi indoctrination attempts. One of the most important political elites of the Swabians was Dr. Franz Kräuter ${ }^{4}$. Kräuter (member of the Romanian parliament) decided to interpellate the German General Consul, Dr. Schwager, in this sensitive matter. The Consul recommended him to travel to Berlin (together with bishop Pacha who was responsible for the confessional schools) and to discuss with the Nazi officials the issue of N.S.-propaganda in Banat (Kräuter, 1995a, p. 31). On February 8, 1934, Augustin Pacha and Franz Kräuter arrived in Berlin (Kräuter, 1995b, p. 124), determined to solve that complex political problem. In the following days, Pacha attended specific events organized by the Catholic clergy in Berlin. He was also received by important personalities (both clerics and politicians) including: the Bishop of Berlin Nikolaus Bares, the leader of R.k.A (Reichsverband für die katholischen Auslandsdeutschen ${ }^{5}$ ) dr. Clemens Emil Scherer, the Apostolic Nuncio Cesare Orsenigo, the former consul in Timisoara, Busse, the Romanian Ambassador in Berlin, Nicolae Petrescu-Comnen, Wilhelm Frick, minister of the Interior, Foreign Minister Konstantin von Neurath. (Kräuter, 1995b, p.124). The proposal to visit Hitler came from the Director of R.k.A Clemens Scherer and Foreign Minister von Neurath, who believed that the propaganda problems in Banat must

${ }^{4}$ Franz Kräuter was born on May 12, 1885 in Vucova (Banat) and died on March 21, 1969 in Freiburg / Breisgau (Germany). He received his doctorate in philology at the University of Budapest in 1907. Between 1920 and 1938 he was elected nine times as a member of the Romanian Parliament. He was a longtime member of the parliamentary committee on education. At the end of 1944, he tried, together with Hans-Otto Roth, to convince the authorities in Romania to stop repressive measures against the German minority. In July 1951 he was arrested and sentenced to hard labor on charges of treason. He was released from prison after 8 years, in May 1959, and handed over to the German authorities (together with Josef Nischbach and the Benedictine nuns Patricia Zimmermann and Hildegardis Wulff) in exchange for two Romanian spies (a.n.).

${ }^{5}$ Association for the Catholic Germans abroad (t.n.). 
be discussed directly with the Nazi leader. Encouraged by the arguments of the two officials and hoping for a rapid resolution of the problem, Bishop Pacha agreed to meet Hitler.

These were the main reasons for Pacha's decision to visit Hitler. The Bishop acted diplomatically and his major objective was to defend the interests of the German minority in Banat. As clerical elite, Augustin Pacha had an authentic power of social representativeness and it is therefore obvious that his decision was a meaningful one. Likewise, the fact that Hitler agreed to receive him in audience, demonstrates that Pacha was a legitimate leader and an authentic elite of the Banat. The long-term consequences of Pacha's decision to meet Hitler appeared to be rather detrimental to the bishop himself but also for the Catholic Church. As previously mentioned, after the war, Pacha was arrested by the Securitate and spent many years in prison. The Communist authorities tried to exploit his supposed NS ideological entanglement (especially for propaganda reasons) but, ultimately, the image of the Catholic Church as traditional pillar in the Romanian society, remained untouched.

\section{Conclusions}

The emergence of National Socialism triggered some unprecedented political events and social imbalances in entire Europe. In interwar Romania the inauspiciously development of economics and the evolving parliamentary crisis (which caused political instability and social mistrust) ultimately led to an increased receptiveness of some social categories for radical ideologies. This particularly unbalanced socio-political context represented the breeding grounds for the rise of extremist organizations such as the Romanian Iron Guard or the Nazi-related groups in Banat and Transylvania. Given the fact that the German minority played an important role and was quite numerous in such multicultural regions, the Nazi ideological stakeholders planed their propaganda campaigns by considering these determinant factors.

In interwar Banat the main objective of National Socialism was to ideologically instrumentalize the public sphere and therefore to control the public agenda. In order to achieve such strategic goals, the Nazi agitators, supervised by the German authorities, systematically tried to indoctrinate certain social categories and to discredit traditional social players, especially the Church. As we mentioned (in a dedicated section of this paper), they partially managed to achieve their goals by gradually taking control (in the first phase propagandistically and later on institutionally) over important educational facilities administrated by the Church. During Second World War, the Nazi organization D.V.i.R (German Ethnic Group in Romania), managed to take over the youth and women organizations administrated by the Catholic Church. The transfer was authorized by the diocese of Timişoara through circular letter 1537/1941, on 6 May 1941 (Archivum Dioecesanum Timisoarense, unordered). One year later, on 16 March 1942, (Hügel, 1968, p. 87) bishop Dr. Augustin Pacha and the head of D.V.i.R Andreas Schmidt signed the document concerning the transfer of catholic schools 
into Nazi possession. On 26 May 1942, this ultimate decision was published in the Romanian National Gazette (Hügel, 1968, p. 87).

In the process of containing the National Socialist ideology and propaganda attempts, Bishop Augustin Pacha and his advisors played a decisive role. The most important fact in his activity as head of the Roman Catholic diocese of Timişoara is that he managed to delay the transfer of youth organizations and confessional educational institutions into Nazi ownership, by almost 10 years. During his incumbency, the diocese of Timişoara became a strong player on the socio-political stage at that time. Even if the systematic anticlerical propaganda campaigns significantly affected the prestige of the clergy in interwar Banat, for most people, regardless of social class or ethno-cultural profile, the Catholic diocese of Timişoara, represented an important factor of social representation and a veritable counterforce to radical political ideologies.

\section{References}

Böhm, J. (1999). Die Deutschen in Rumänien und das Dritte Reich. 1933-1940. Frankfurt am Main: Peter Lang Verlag.

Călin, C. (2009). Dr. H.C. Augustin Pacha (1870-1954). Succint excurs biografic al primului episcop romano-catolic de Timişoara. Banatica, No. 19, pp. 203-260.

Hockl, H. (1940). Das deutsche Banat. Seine geschichtlich-politische Entwicklung und Aufgabe. Temeschburg: Buchdruckerei Anwender\&Sohn.

Hügel, K. (1957). Abriss der Geschichte des Donauschwäbischen Schulwesens. München: Verlag des Südostdeutschen Kulturwerks.

Hügel, K. (1968). Das Banater deutsche Schulwesen in Rumänien von 1918 bis 1944. München:Verlag des Südostdeutschen Kulturwerks.

Jenkins, R. (2008). Rethinking Ethnicity. Second Edition. London: Sage Publications.

Kräuter, F. (1995). Meine "Schuld" und meine Sühne. Karlsruhe/Temeswar: Mirton-Verlag.

Kräuter, F. (1995). Erinnerungen an Bischof Pacha. Bukarest: ADZ-Verlag.

Malesevic, S. (2006). Identity as Ideology. Understanding Ethnicity and Nationalism. New York: Palgrave Macmillan.

Maner, H. (2004). Parlamentarismul în România 1930-1940. Bucharest: Editura Enciclopedică.

Milata, P. (2009). Zwischen Hitler, Stalin und Antonescu. Rumäniendeutsche in der Waffen-SS. 2. Auflage. Köln: Böhlau.

Petri, A. (1992). Biographisches Lexikon des Banater Deutschtums. Marquartstein: Th. Breit Verlag. Schmitt, C. (1996). Roman Catholicism and Political Form. Westport: Greenwood Press.

Smith, A. (1998). Nationalism and modernism: a critical survey of recent theories of nations and nationalism. London: Routledge.

Sugar, P. (2002). Naţionalismul est-european în secolul al XX-lea. Bucharest: Curtea Veche.

Wodak, R. et. al. (2009). The Discursive Construction of National Identity. Second Edition. Edinburgh: Edinburgh University Press. 


\section{Archives:}

1. Archivum Dioecesanum Timisoarense, ADT, (Der Ruf: Anonim, Kameraden, Timişoara, Ianuarie 1937).

2. Das Bundesarchiv: BArch, NS 19/1077 (Andreas Schmidt, Volksgruppenführer der Deutschen Volksgruppe in Rumänien - Differenzen mit dem SD in Rumänien, Verwendung bei Kriegsende in einem Einsatzkommando).

3. Politisches Archiv des Auswärtigen Amtes: PA AA, Bucharest 136/2587 (Römisch-Katholische Kirche).

\section{Author}

Mihai A. Panu

mihai.panu@e-uvt.ro - West University, Department of Political Science (Timisoara) 